\title{
Lanosterol 14 $\alpha$-demethylase (CYP51), NADPH-cytochrome P450 reductase and squalene synthase in spermatogenesis: late spermatids of the rat express proteins needed to synthesize follicular fluid meiosis activating sterol
}

\author{
G Majdič, M Parvinen ${ }^{1}$, A Bellamine ${ }^{2}$, H J Harwood $\mathbf{~ J r}^{3}$, \\ W W Ku ${ }^{3}$, M R Waterman ${ }^{2}$ and D Rozman ${ }^{4}$ \\ Veterinary Faculty, Clinic of Reproduction, Cesta v Mestni log 47a, 1000 Ljubljana, Slovenia \\ ${ }^{1}$ Institute of Biomedicine, Department of Anatomy, University of Turku, Kiinamyllynkatu 10, FIN-20520 Turku, Finland \\ ${ }^{2}$ Department of Biochemistry, Vanderbilt University School of Medicine, Nashville, Tennessee 37232-0146, USA \\ ${ }^{3}$ Pfizer Central Research, Department of Metabolic Diseases, Box No. 0438, Eastern Point Road, Groton, Connecticut 06340, USA \\ ${ }^{4}$ Institute of Biochemistry, Medical Center for Molecular Biology, Medical Faculty University of Ljubljana, Vrazov trg 2, SI-1000 Ljubljana, Slovenia \\ (Requests for offprints should be addressed to D Rozman; Email: rozman@ibmi.mf.uni-lj.si) \\ (G Majdič is now at Department of Internal Medicine, UT Southwestern Medical Center, Dallas, Texas 75235-8857, USA)
}

\begin{abstract}
Lanosterol 14a-demethylase (CYP51) is a cytochrome P450 enzyme involved primarily in cholesterol biosynthesis. CYP51 in the presence of NADPH-cytochrome P450 reductase converts lanosterol to follicular fluid meiosis activating sterol (FF-MAS), an intermediate of cholesterol biosynthesis which accumulates in gonads and has an additional function as oocyte meiosis-activating substance. This work shows for the first time that cholesterogenic enzymes are highly expressed only in distinct stages of spermatogenesis. CYP51, NADPH-P450 reductase (the electron transferring enzyme needed for CYP51 activity) and squalene synthase (an enzyme preceding CYP51 in the pathway) proteins have been studied. CYP51 was
\end{abstract}

detected in step 3-19 spermatids, with large amounts in the cytoplasm/residual bodies of step 19 spermatids, where P450 reductase was also observed. Squalene synthase was immunodetected in step 2-15 spermatids of the rat, indicating that squalene synthase and CYP51 proteins are not equally expressed in same stages of spermatogenesis. Discordant expression of cholesterogenic genes may be a more general mechanism leading to transient accumulation of pathway intermediates in spermatogenesis. This study provides the first evidence that step 19 spermatids and residual bodies of the rat testis have the capacity to produce MAS sterols in situ.

Journal of Endocrinology (2000) 166, 463-474

\section{Introduction}

Lanosterol $14 \alpha$-demethylase (CYP51) is a member of the diverse cytochrome P450 superfamily and is involved in cholesterol biosynthesis in mammals (Nelson 1999). CYP51 resides in the endoplasmic reticulum (Trzaskos et al. 1986) and oxidatively demethylates substrates in the presence of NADPH, molecular oxygen and the microsomal electron transferring enzyme, NADPH-cytochrome P450 reductase (Fischer et al. 1991, Shyadehi et al. 1996). Lanosterol, the major endogenous substrate for mammalian CYP51, is synthesized from squalene through sequential epoxidation and cyclization reactions that are catalyzed by squalene epoxidase and oxidosqualene cyclase (Fig. 1). Squalene, which is the first pathway intermediate committed to the formation of cholesterol, is produced directly from the branch-point substrate, farnesyl pyrophosphate, through the action of squalene synthase (Fig. 1A). CYP51 removes the $14 \alpha$-methyl group from lanosterol, forming 4,4,-dimethyl $5 \alpha$-cholesta, 8,14,24-diene-3 $\beta$-ol (Fig. 1B), also known as follicular fluid meiosis activating sterol (FF-MAS). At least six enzymatic steps after CYP51 are needed for the production of cholesterol from its precursors (Fig. 1C).

Cholesterol biosynthesis and its coordinate regulation by the sterol regulating element binding protein (SREBP)dependent pathway is well characterized in the liver (Goldstein \& Brown 1990, Brown \& Goldstein 1998), but very little is known about this process in the male gonad, especially in germ cells. Human sperm lysates were shown to have the capacity to synthesize cholesterol from $\left[{ }^{14} \mathrm{C}\right]$ acetate in vitro, yet the activity seems to be too low to contribute significantly to the free cholesterol content of the sperm (Gunasegaram et al. 1995, Cross 1998). In 
A

squalene
farnesyl
pyrophthase $\stackrel{\text { squalene } \stackrel{\begin{array}{c}\text { squalene } \\ \text { epoxidase }\end{array}}{\longrightarrow} \begin{array}{c}\text { oxidosqualene } \\ \text { squalene } \\ \text { epoxide }\end{array}}{\text { cyclase }} \longrightarrow$ lanosterol

B<smiles>CC(C)=CCCC1CCC2(C)CCC1=C1C2CCC2C1(C)CCC(O)C2(C)C</smiles>

lanosterol
$3 \mathrm{NADPH}+3 \mathrm{H}+$

$+3 \mathrm{O}_{2}$

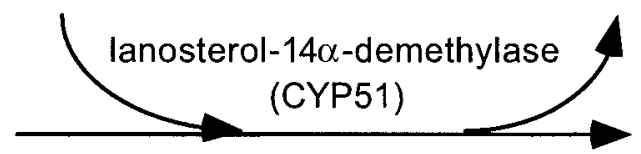

NADPH cytochrome-P450 reductase
3NADP+

$+4 \mathrm{H}_{2} \mathrm{O}+\mathrm{HCOOH}$<smiles>CC(C)=CCCC(C)C1CCC2=C3CCC4C(C)(CCC(O)C4(C)C)C3=CCC21</smiles>

FF-MAS

\section{sterol $\triangle 14-$ reductase FF-MAS $\rightarrow$ T-MAS

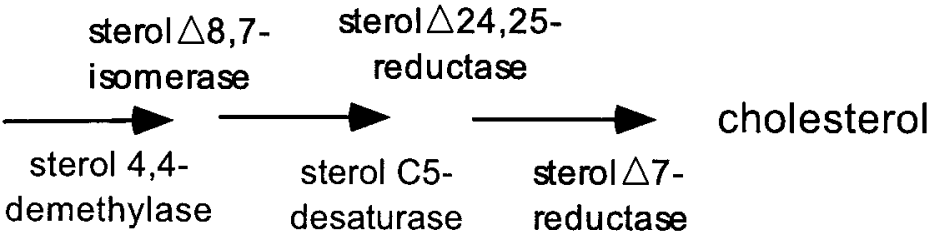

Figure 1 Enzymatic conversion of farnesyl pyrophosphate to cholesterol. (A) Conversion of farnesyl pyrophosphate to lanosterol. Farnesyl pyrophosphate is formed from acetate through a multistep pathway that includes the key intermediates mevalonate and isopentenyl pyrophosphate (not shown). (B) Lanosterol 14 $\alpha$-demethylase (CYP51) reaction. The methyl group at position 14 is subjected to three consecutive cytochrome P450 oxidation cycles, the intermediates of the reaction being the alcohol and aldehyde. The carbon at position 14 is removed as formic acid during the third oxidation. In each cytochrome P450 cycle, a pair of electrons is transferred from NADPH to NADPH-cytochrome P450 reductase and on the cytochrome P450 enzyme, CYP51. There is no catalytic activity in the absence of NADPH-cytochrome P450 reductase. (C) Conversion of FF-MAS to cholesterol. At least six enyzmes after CYP51 participate in cholesterol biosynthesis. The precise order of the last three reactions might be tissue-specific and remains a matter of discussion. T-MAS is another sterol having in vitro meiosis activating activity.

contrast to the majority of tissues in which cholesterol is the main product, male and female gonads overproduce two late intermediates of the cholesterol biosynthetic pathway, follicular fluid meiosis activating sterol (FF-MAS; 4,4-demethyl-5 $\alpha$-cholesta-8,14,24-triene- $3 \beta$ $\mathrm{ol}$ ) and testis meiosis activating sterol (T-MAS; 4,4dimethyl-5 $\alpha$-cholesta-8,24-diene-3 $\beta$-ol) (Byskov et al. 1995, 1999). Both tissue-isolated FF-MAS (Byskov et al. 1995), the product of lanosterol 14a-demethylase (CYP51) and chemically synthesized FF-MAS (Grondahl et al. 1998), and T-MAS, the product of the sterol $\Delta 14$-reductase, stimulate reinitiation of meiosis in mouse oocytes in vitro and are believed to have important, but not yet fully understood, roles in fertilization (Byskov et al. 1995, 1999, Grondahl et al. 1998).

The first mammalian CYP51 gene was characterized in 1994 (Aoyama et al. 1994) and extensively studied since then (Aoyama et al. 1996, Rozman et al. 1996a,b, Strömstedt et al. 1996, Noshiro et al. 1997). The gene shows remarkable conservation between species: for example, the amino acid homology between the human and the rat genes is $93 \%$ (Strömstedt et al. 1996). CYP51 mRNA is expressed in all mammalian tissues, the expression being an order of magnitude greater in male germ 
cells of the testis compared with any other tissue/cell type (Strömstedt et al. 1998). Testis is also the organ in which the greatest concentrations of accumulating MAS sterols have been detected (Byskov et al. 1999). Thus, it seems likely that overexpression of CYP51 mRNA influences accumulation of MAS sterols in the testis. In situ hybridization studies show a stage-specific expression of CYP51 mRNA in rat (Strömstedt et al. 1998) and mouse (Rozman et al. 1999) testis, with the greatest amounts in postmeiotic germ cells, the spermatids. The earliest detection of CYP51 mRNA is in round spermatids of steps 3-5. Thereafter, expression increases, reaching the highest level in elongating spermatids of steps $7-14$. CYP51 mRNA expressed in germ cells is translated into the protein, as increased CYP51 activity is observed in germ cells of sexually mature rats (Strömstedt et al. 1998).

This study investigated which cell types of the testis have the greatest potential to synthesize MAS sterols in situ, by describing immunolocalization of lanosterol $14 \alpha$-demethylase and NADPH-cytochrome P450 reductase - two enzymes needed to produce FF-MAS in the rat testis. By also monitoring squalene synthase, we have been able to describe the stage-specific expression of post-farnesyl pyrophosphate enzymes of cholesterol biosynthesis in testicular germ cells, giving insights into the molecular basis by which accumulation of intermediates in cholesterol biosynthesis can occur.

\section{Materials and Methods}

\section{Animals and tissue recovery}

Rat testicular tissue was obtained from sexually mature (90-day-old) male Wistar rats after perfusion fixation using Bouin's solution as described before (Millar et al. 1993). Rat liver was obtained from sexually mature 90-day-old animals and was immersion-fixed in Bouin's solution for $6 \mathrm{~h}$. After fixation, all tissues were either stored in $70 \%$ ethanol until further processing or immediately processed into paraffin wax using a Shandon tissue processor (Millar et al. 1993).

\section{Purification of the human CYP51 protein and preparation of antibodies}

Human CYP51 was expressed in Escherichia coli Topp3 strain as described previously (Strömstedt et al. 1996). Four histidine codons were introduced into the $3^{\prime}$-end of the cDNA 3 by standard cloning procedures (Imai et al. 1993), to facilitate protein purification. The E. coli cells expressing human CYP51 were collected by centrifugation at $2000 \mathrm{~g}$ for $10 \mathrm{~min}$ at $4{ }^{\circ} \mathrm{C}$. All purification steps were performed at $4{ }^{\circ} \mathrm{C}$. The cell pellet was resuspended at $10 \mathrm{ml} / \mathrm{g}$ of cell weight in $100 \mathrm{mM}$ Tris $-\mathrm{HCl}$ buffer $\mathrm{pH} 7 \cdot 4$ containing $500 \mathrm{mM}$ sucrose and $1 \mathrm{mM}$ EDTA.
Lysozyme was added to a final concentration of $0.5 \mathrm{mg} / \mathrm{ml}$. An equal volume of ice-cold $0.1 \mathrm{mM}$ EDTA, $\mathrm{pH} 8$, was slowly added and the mixture stirred for $30 \mathrm{~min}$. The spheroplasts were collected by centrifugation at $2000-5000 \mathrm{~g}$ for $15 \mathrm{~min}$ and resuspended at $5 \mathrm{ml} / \mathrm{g}$ in potassium phosphate buffer $\mathrm{pH} 7 \cdot 4$ containing $30 \%$ glycerol, $0.1 \mathrm{mM}$ dithiothreitol (DTT), $0.1 \mathrm{mM}$ EDTA, $0.1 \mathrm{mM}$ phenylmethylsulphonyl fluoride (PMSF), $1 \mathrm{mg} / \mathrm{ml}$ DNase and $10 \mathrm{mM}$ lanosterol. Spheroplasts were homogenized using a Teflon homogenizer. Triton X-114 (Boehringer Mannheim) was added to a final concentration of $0.7 \%$ and the mixture was stirred for $20 \mathrm{~min}$ (Halkier et al. 1996). The P450-rich phase was separated by centrifugation at $100000 \mathrm{~g}$ for $30 \mathrm{~min}$ and diluted $1: 10$ in potassium phosphate buffer $\mathrm{pH} 7 \cdot 4$ containing $20 \%$ glycerol, $0 \cdot 1 \mathrm{mM}$ PMSF, $0 \cdot 4 \%$ Triton X-100 and $10 \mathrm{mM}$ lanosterol. The diluted $\mathrm{P} 450$ suspension was applied to a $\mathrm{Ni}^{2+}$ nickel nitrilotriacetic acid (NTA) affinity column (Qiagen). The column was washed with $50 \mathrm{mM}$ potassium phosphate buffer $\mathrm{pH} 7 \cdot 4$ containing $500 \mathrm{mM} \mathrm{NaCl}$, $20 \%$ glycerol, $50 \mathrm{mM}$ glycine, $0.4 \%$ Triton X-100 and $10 \mathrm{mM}$ lanosterol. The human CYP51 was eluted with the same buffer containing $40 \mathrm{mM}$ histidine instead of glycine. The CYP51 protein was $>90 \%$ pure by SDSPAGE and silver staining. Antibodies against the human CYP51 were raised by injecting New Zealand rabbits with $0.5 \mathrm{mg} \mathrm{Ni}{ }^{2+} \mathrm{NTA}$-eluted protein mixed with one volume of Freund's complete adjuvant (Sigma). The same amount of protein was used for a booster 4 weeks later, as a mixture with Freund's incomplete adjuvant (Sigma). The antisera collected from a bleed 4 weeks after the second injection were assayed by immunoblot analysis and seen to recognize both the purified and the tissue-derived CYP51 (Fig. 2).

\section{Preparation of the human squalene synthase protein and antibodies}

The human squalene synthase protein used in preabsorption studies is a doubly truncated form of the membranebound protein that has been rendered soluble by removing 30 amino acids from the $\mathrm{N}$-terminus and 46 amino acids from the C terminus (Thompson et al. 1998). The protein, which was overexpressed in E. coli and purified to homogeneity as described (Thompson et al. 1998), was homogenous on SDS-PAGE and mass spectroscopy with the measured mass of $39196 \mathrm{Da}$, and was maintained at $-20{ }^{\circ} \mathrm{C}$ at a protein concentration of $4 \mathrm{mg} / \mathrm{ml}$ in $20 \mathrm{mM}$ Tris $\mathrm{pH} 7 \cdot 4,5 \mathrm{mM}$ DTT, $2 \mathrm{mM} \mathrm{MgCl} 2,0 \cdot 5 \mathrm{M} \mathrm{NaCl}$ and $50 \%$ glycerol. Squalene synthase antibody was raised in New Zealand white rabbits against peptide-keyhole limpet hemocyanin (KLM) conjugates corresponding to the $\mathrm{C}$ terminus $\left(\mathrm{CH}_{3} \mathrm{CO}-\mathrm{CDSDPS}\right.$ SSKTRQIISTIRTQN$\mathrm{COOH}$ ) of the truncated protein. The antiserum specifically recognizes the human squalene synthase protein, 


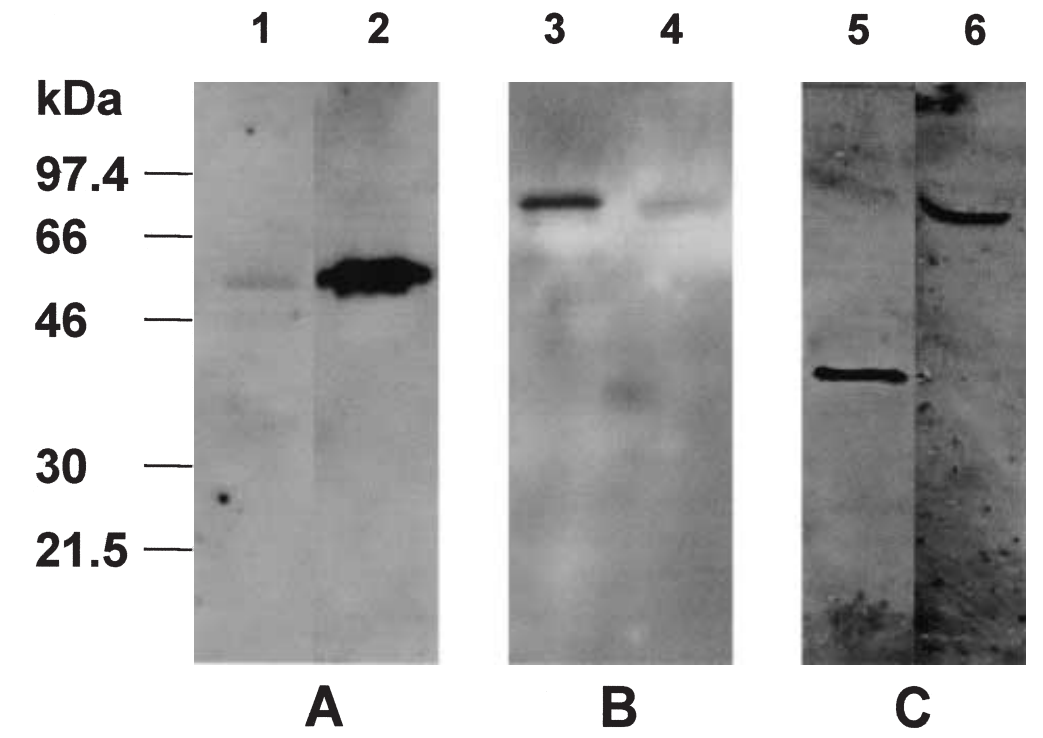

Figure 2 Detection of CYP51 (A), NADPH-P450 reductase (B) and squalene synthase $(C)$ proteins by immunoblot analysis. Lane 1 , rat germ cell proteins $(10 \mu \mathrm{g})$; lane 2, the purified human CYP51 protein (85 ng); lane 3, rat liver microsomal $(100000 \mathrm{~g})$ proteins $(10 \mu \mathrm{g})$; lane 4 , rat germ cell proteins $(10 \mu \mathrm{g})$; lane 5, purified truncated $\sim 39 \mathrm{kDa}$ human squalene synthase protein (100 ng); lane 6, mouse liver microsomal proteins $(10 \mu \mathrm{g})$. Rainbow protein molecular mass markers (Amersham) are shown at the left $(\mathrm{kDa})$. Human and rat CYP51 proteins have a molecular mass of $\sim 55 \mathrm{kDa}$, rat NADPH-P450 reductase protein a molecular mass of $72-74 \mathrm{kDa}$ (Guengerich et al. 1981), and squalene synthase is detected as a protein of $\sim 60 \mathrm{kDa}$ in rat and mouse.

both in purified fractions and in cell lysates, at dilutions between 1:200 and 1:2500, and also crossreacts with the rat enzyme.

\section{Preparation of the rat NADPH-cytochrome P450 reductase protein and antibodies}

The antibodies kindly provided by Dr F P Guengerich (Vanderbilt University) were raised against the rat liver NADPH-cytochrome P450 reductase purified from liver microsomes as described elsewhere (Guengerich et al. 1981). The antibody recognizes a single protein by immunoblot analysis (Guengerich et al. 1987). Recombinant rat $\mathrm{NADPH}$-cytochrome $\mathrm{P} 450$ reductase was expressed in E. coli and purified as described elsewhere (Jenkins \& Waterman 1998). For the preabsorption studies, $45 \cdot 1 \mathrm{mM}$ protein was used.

\section{Immunocytochemistry}

Sections $5 \mu \mathrm{m}$ thick were mounted on slides coated with 3-aminopropyl triethoxysilane (TESPA; Sigma) and dried overnight at $37^{\circ} \mathrm{C}$. Before incubation with primary antibody, sections were dewaxed, rehydrated in graded ethanols, washed in water and $0.05 \mathrm{M}$ Tris- $\mathrm{HCl}(\mathrm{pH}$ $7 \cdot 4)-.85 \% \mathrm{NaCl}$ (TBS) and endogenous peroxidases were blocked by incubating the sections for $30 \mathrm{~min}$ in $1 \% \mathrm{H}_{2} \mathrm{O}_{2}$ in TBS. Sections were subjected to antigen retrieval (Shi et al. 1993) by microwaving in $0.01 \mathrm{M}$ citrate buffer $(\mathrm{pH}$ 6.0) on full power for $20 \mathrm{~min}$, and were thereafter left standing for $20 \mathrm{~min}$ without disturbance. Sections were then washed for $5 \mathrm{~min}$ in TBS and blocked in TBS containing native goat serum (Dako, Copenhagen, Denmark) diluted 1:5 in TBS. The rabbit polyclonal antibodies against human CYP51 protein were used at a dilution of $1: 20$, the rabbit polyclonal antibodies against human squalene synthase were used at dilution of 1:100, and the rabbit polyclonal antibodies against human NADPHcytochrome P450 reductase were used at a dilution of either 1:100 or 1:200. The immunostaining procedure was similar with all antibodies, which were diluted in TBS containing normal goat serum $(5: 1, \mathrm{v} / \mathrm{v})$ before incubation on sections under plastic coverslips overnight at $4{ }^{\circ} \mathrm{C}$. The following day, coverslips were removed and sections were washed twice in TBS (5 min each wash), incubated for 30 min with a 1:60 dilution of goat anti-rabbit IgG (Dako) in TBS and then, washed again in TBS (twice for $5 \mathrm{~min}$ ). For detection of bound antibodies, sections were incubated with a 1:100 dilution of rabbit peroxidase-antiperoxidase complex (Dako) in TBS for $30 \mathrm{~min}$ and then washed twice in TBS (5 min each). Color was developed by incubating sections in a mixture of $0.05 \%(\mathrm{w} / \mathrm{v})$ 
3,3'-diaminobenzidine tetrahydrochloride (Sigma) in $0.05 \mathrm{M}$ Tris $-\mathrm{HCl}, \mathrm{pH} 7 \cdot 4$ and $0 \cdot 01 \%$ hydrogen peroxide. After 5-15 min, sections were washed in distilled water, counterstained with hematoxylin, dehydrated in graded ethanols, cleared in xylene and coverslipped using Pertex mounting medium (CellPath plc, Hemel Hempstead, UK). Specificity of the antibodies was evaluated by using rabbit serum instead of primary antibodies and by preabsorbing the primary antibodies overnight with a 20 -fold excess of the corresponding protein or peptide before staining. Photomicrographs were taken using a Nikon microphot FXA.

\section{Preparation of rat germ cell protein extracts}

Germ cells from two sexually mature Sprague-Dawley rats (Harlan) were prepared in each experiment as described elsewhere (Strömstedt et al. 1998). Briefly, decapsulated testes were thoroughly minced with an array of sealed razor blades and treated with DNAse and trypsin. This procedure destroys most of the Sertoli and Leydig cells, but germ cells remain intact (Meistrich et al. 1973). Our preparations of germ cells contained premeiotic spermatocytes in addition to postmeiotic round and elongating spermatids (Strömstedt et al. 1998). No Sertoli cells were observed; Leydig cells were present at less than 1\% of the total cell population (Strömstedt et al. 1998). Germ cells were pelleted, washed and suspended in $5 \mathrm{ml}$ of assay buffer and hand-homogenized on ice by at least 70 strokes. The $1500 \mathrm{~g}$ supernatant was prepared and the protein content measured (Bio-Rad, Hemel Hempstead, UK). Contamination with testis somatic cells was determined by morphological examination of air-dried smears stained with periodic acid Schiff-hematoxylin (Meistrich et al. 1973).

\section{Preparation of microsomes, protein extracts and CYP51 activity}

Liver protein extracts were prepared from the same sexually mature, 52-56-day-old rats as described previously for the testis protein extracts (Strömstedt et al. 1998). Two 52-56-day-old sexually mature SpragueDawley rats (Harlan) were killed in each of three independent experiments. The livers were removed, washed three times with $4{ }^{\circ} \mathrm{C} 0.25 \mathrm{M}$ sucrose, minced with razor blades, diluted $1: 20$ with $4{ }^{\circ} \mathrm{C}$ assay buffer $(100 \mathrm{mM}$ potassium phosphate buffer $\mathrm{pH} 7 \cdot 4,0 \cdot 1 \mathrm{M}$ DTT, $0 \cdot 1 \mathrm{mM}$ EDTA, 20\% glycerol) and homogenized by 10 strokes of a Dounce tissue homogenizer, on ice. Cell debris was removed by centrifugation for $15 \mathrm{~min}$ at $1500 \mathrm{~g}$ and $4{ }^{\circ} \mathrm{C}$ and protein content of the supernatant measured (BioRad). Microsomal proteins for immunoblot analysis were prepared by recentrifuging the supernatant at $100000 \mathrm{~g}$ and $4{ }^{\circ} \mathrm{C}$ for $1 \mathrm{~h}$ and suspending the S-100 pellet in one half of the initial amount of assay buffer. Adult mouse liver microsomal $(100000 \boldsymbol{g})$ proteins were prepared by the same procedure. The CYP51 activity assay and HPLC separation of sterols were performed exactly as described previously (Strömstedt et al. 1996). Each reaction contained 3-8 $\mathrm{mg}$ of the liver total protein, $1.6 \times 10^{5}$ c.p.m. pure $\left[{ }^{3} \mathrm{H}\right] 24,25$-dihydrolanosterol (a gift of Dr Trzaskos, DuPont-Merck), $25 \mathrm{nmol}$ each of a mixture of unlabeled lanosterol and 24,25-dihydrolanosterol in Triton WR $1339(16 \mathrm{mg} / \mathrm{ml}$ in acetone), and inhibitors $\mathrm{NaCN}$ $(0.5 \mathrm{mM})$ and AY9944 (0.1 mM; a gift of Dr Trzaskos, DuPont-Merck) to block further metabolism of reaction products.

\section{Immunoblot analysis}

Proteins were separated on $8-10 \%$ SDS polyacrylamide gels and transferred by the Sammy Dry electroblotting apparatus (Schleicher \& Schuell, Dassel, Germany) to Optitran BA-S 83 nitrocellulose membranes using the continuous transfer buffer $(50 \mathrm{mM}$ Tris, $39 \mathrm{mM}$ glycine, $20 \%$ methanol) at $3.5 \mathrm{~mA} / \mathrm{cm}^{2}$. The air-dried membrane was incubated for $1 \mathrm{~h}$ in $10 \mathrm{ml} 5 \%$ enhanced chemiluminescence (ECL) blocking agent (Amersham) in TBS-T (20 mM Tris pH 7·4, $300 \mathrm{mM} \mathrm{NaCl}, 40 \mathrm{mM} \mathrm{KCl}, 0 \cdot 1 \%$ Tween 20) buffer. The blocking agent solution was decanted and membranes incubated in $10 \mathrm{ml}$ of the primary antibody solutions in TBS-T buffer for $1 \mathrm{~h}$ : (a) rabbit polyclonal antibodies against human CYP51 diluted 1:300; (b) rabbit polyclonal antibodies against human squalene synthase diluted 1:200; (c) rabbit polyclonal antibodies against rat NADPH-P450 reductase diluted 1:1500. Three washing steps in $10 \mathrm{ml}$ fresh TBS-T buffer (15 min-1 h and twice for $5 \mathrm{~min}$ ) preceded the 1-h incubation in $10 \mathrm{ml}$ of the secondary antibody solution (rabbit IgG horseradish peroxidase-linked whole antibody, diluted 1:3000 in TBS-T buffer). Membranes were then washed three times in TBS-T buffer as before. Detection of proteins was performed by the ECL western blotting kit (Amersham) using autoradiography as described by the manufacturer. When more than one protein was analysed on the same membrane, the first antibody was removed completely by incubating the membrane in $100 \mathrm{mM}$ 2-mercaptoethanol, 2\% SDS, $62.5 \mathrm{mM}$ Tris $-\mathrm{HCl} \mathrm{pH} 6.7$ at $50{ }^{\circ} \mathrm{C}$ for $30 \mathrm{~min}$. The membrane was then washed twice for $10 \mathrm{~min}$ in TBS-T buffer at room temperature. The subsequent steps from blocking to ECL detection were same as descibed above.

\section{Results}

Immunodetection of CYP51 enzyme in testis and liver

Rat germ cell proteins were subjected to immunoblot analysis using rabbit anti-human CYP51 antibody. The human histidine-conjugated, bacterially expressed CYP51 protein had a molecular mass of $\sim 55 \mathrm{kDa}$ (Fig. 2A, lane $2)$, which is in accordance with the predicted value 


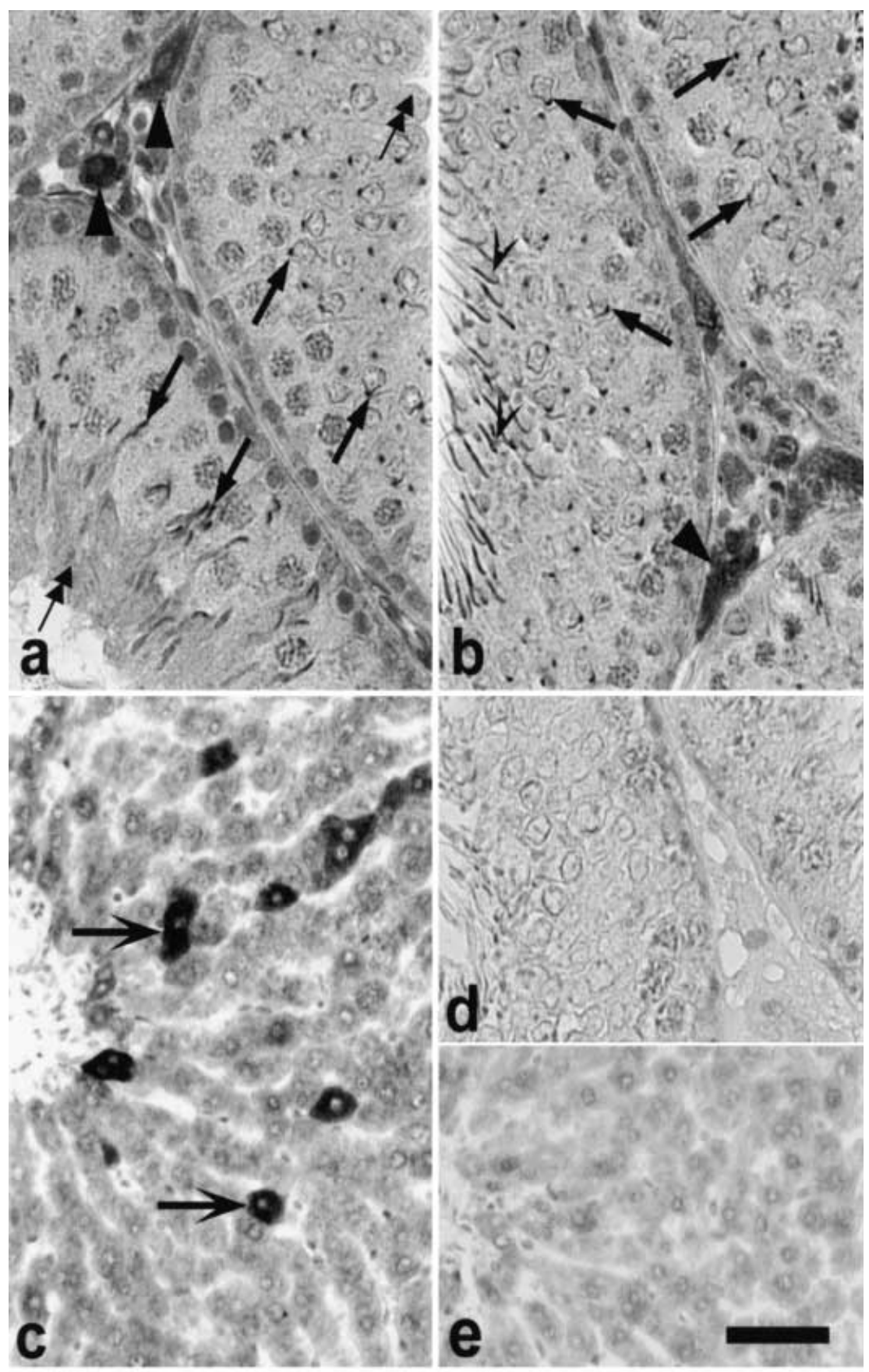

A

Figure $3(\mathrm{~A})$

deduced from the cDNA. A protein of identical size was detected in rat germ cell preparations (Fig. 2A, lane 1) and in rat liver (not shown). Using this antibody, the highest level of immunodetectable CYP51 protein was found in Leydig cells of sexually mature rat testis (Fig. 3A, a,b arrowheads) and also in haploid germ cells. Interestingly, in germ cells the CYP51 protein was not localized only to the cytoplasm where the endoplasmic reticulum resides (double arrows), but also to the acrosomal region of round and elongating spermatids (arrows, Fig. 3A, a,b; Fig. 3B). 

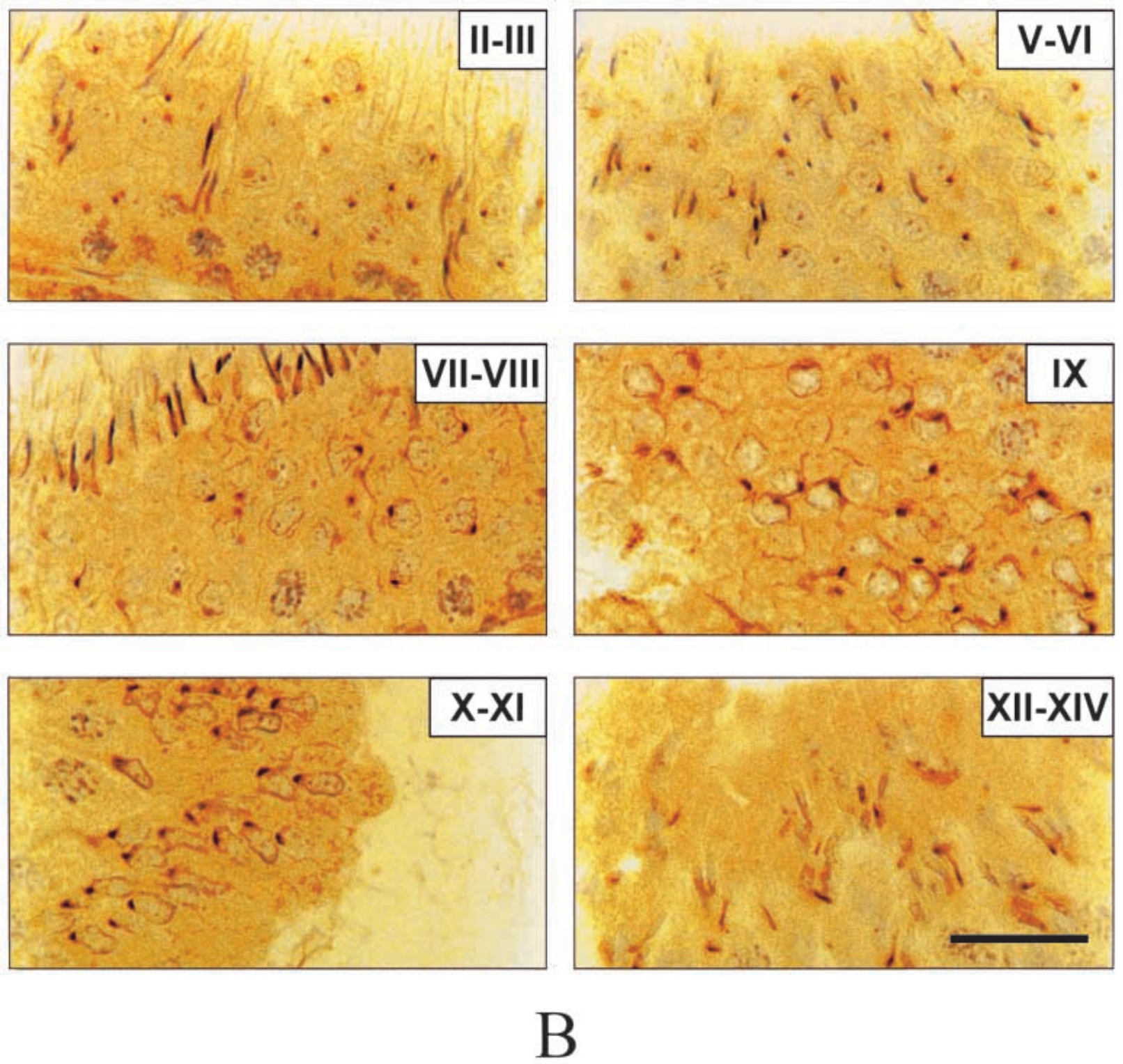

Figure $3(B)$

Figure 3 (A) Immunodetection of CYP51 in rat testis (a,b,d) and liver (c,e). (a,b,c) Stained with the anti-human CYP51 antibody; $(\mathrm{d}, \mathrm{e})$ stained with the same antibody preadsorbed with the purified CYP51 protein. Arrows, acrosomes of round and elongated spermatids; open arrowheads, staining in step 19 spermatids and residual bodies; arrowheads, staining in Leydig cells; doubleheaded arrows, staining of cytoplasm. Note an intense 'ring' of staining in the cytoplasm of elongated spermatids in (a). The cytoplasm of round spermatids shows low levels of the CYP51 protein, seen as a weak 'ring' of staining, separating spermatocytes and spermatids. Bar represents $50 \mu \mathrm{m}$. (B) Stage-specific immunodetection of CYP51 in spermatogenesis of the rat. Spermatogenesis stages are indicated by roman numerals. Bar represents $50 \mu \mathrm{m}$. Staining of the basal cell types is considered to be non-specific, as it was not completely removed by the preadsorption experiment.

CYP51 protein was immunodetected also in residual bodies (Fig. 3A, b, open arrowheads; Fig. 3B, stage VII-VIII), but only background levels were found in early germ cells, the spermatogonia and spermatocytes. The specificity of staining was checked in control testis sections in which the primary antibody was replaced with nonimmune serum (not shown) or with CYP51 protein preadsorbed antibodies (Fig. 3A, d). By careful examination of testis slides containing germ cells in different stages of their development (Fig. 3B), the pattern of CYP51 


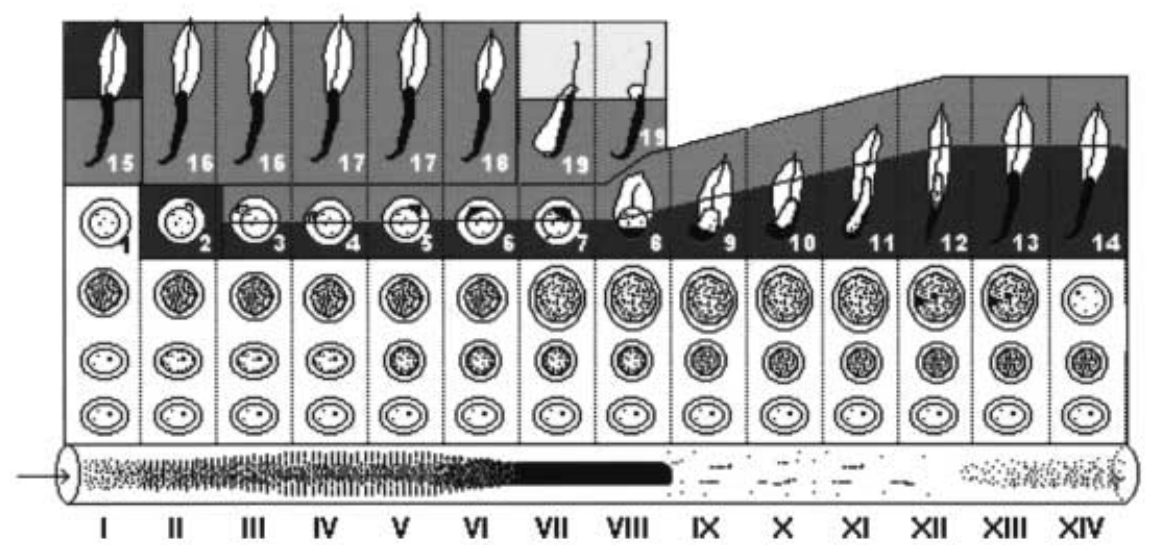

Figure 4 Pattern of immunolocalization of squalene synthase (dark gray), CYP51 (medium gray) and NADPH-cytochrome P450-reductase (light gray) proteins during spermatogenesis of the rat. A map of spermatogenesis shows the stages of the cycle of the seminifereous epithelium indicated by roman numerals (Russell et al. 1990). The arrow indicates a schematic tracing of transilluminated living seminiferous tubule at the same stages of the cycle (Parvinen \& Vanha-Perttula 1972). Arabic numerals present steps of spermiogenesis. Step 19 spermatids release their cytoplasm as residual bodies and move to the lumen of the seminiferous epithelium. Note the coexpression of CYP51 and NADPH-cytochrome P450 reductase in step 19 spermatids.

protein immunodetection in spermatogenesis in rat was established (Fig. 4, medium gray colour). The greatest concentrations of CYP51 protein were detected in round spermatids of stages III-VII (steps 3-7), in elongated spermatids of stages VIII-XIV (steps 8-14) and in stage VII (step 19). Low levels of CYP51 protein were observed also in elongated spermatids of stages I-VI (steps 15-18).

Immunodetection of CYP51 protein was monitored also in liver of chow-fed rats. A low level of expression was observed in the majority of hepatocytes, but some contained significantly greater concentrations of CYP51 protein (Fig. 3A, c, arrow). No positive signal was detected in control liver sections when primary antibody was replaced with preadsorbed antibody (Fig. 3A, e).

\section{Immunodetection of $\mathrm{NADPH-cytochrome} \mathrm{P} 450$ reductase in the testis}

Using the anti-rat NADPH-P450 reductase antibody, NADPH-P450 reductase was detected as a protein of $\sim 72 \mathrm{kDa}$ in rat liver (Fig. $2 \mathrm{~B}$, lane 3 ) and rat male germ cells (Fig. 2B, lane 4). A high concentration of NADPHcytochrome $\mathrm{P} 450$ reductase protein was detected in Leydig cells (Fig. 5a, arrowhead) and in residual bodies (Fig. 5a, arrow) inside the seminiferous tubules. Staining was also found in elongated spermatids of stages VII-VIII (step 19). Despite the fact that all germ cells probably express low levels of the ubiquitous NADPH-P450 reductase, high levels of the enzyme were detectable exclusively in mature, step 19 elongated spermatids, which are ready to be released to the lumen (Fig. 4, light gray colour). No NADPH-cytochrome $\mathrm{P} 450$ reductase protein was detected in sections incubated with non-immune serum (not shown) or with preadsorbed antibodies (Fig. 5b, rat).

\section{Immunodetection of squalene synthase}

Squalene synthase is the third housekeeping cholesterogenic enzyme of which expression in spermatogenesis has been studied. The purified human truncated squalene synthase protein has a molecular mass of $\sim 39 \mathrm{kDa}$ (Fig. 2C) and is easily detected by the anti-human squalene synthase antibody raised against the C-terminal peptide of the protein. Squalene synthase is detected as a protein of $\sim 60 \mathrm{kDa}$ in mouse and rat liver (Fig. 2C, lane 6) and in germ cells (not shown). The greatest concentrations of squalene synthase protein were immunodetected in Leydig cells (Fig. 6a, arrowheads) and in the acrosomal region (arrow) of round and elongated spermatids (Fig. 6a). No immunostaining was detected using non-immune rabbit serum (not shown) or preadsorbed antibodies (Fig. 6b). The pattern of immunolocalization of squalene synthase during spermatogenesis in rat is shown in Fig. 4 (dark gray color). The protein was detected continuously from stage II-XIV (steps 2-14) round and elongated spermatids and in stage I (step 15) elongated spermatids, but was not detected in later steps of spermatogenesis.

\section{CYP51 enzymatic activity in rat liver and in testis}

CYP51 enzymatic activity was measured in total liver protein extracts and in liver microsomes of sexually mature 

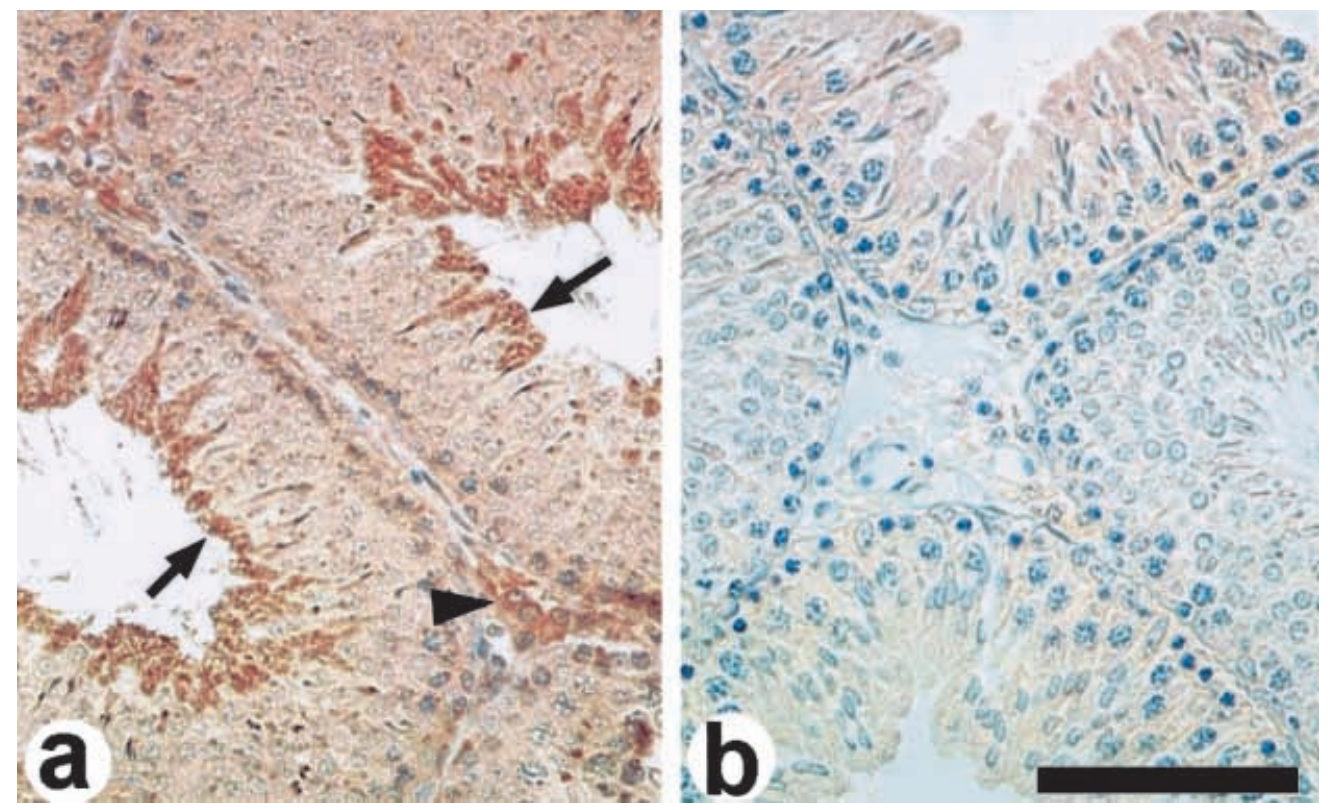

Figure 5 Immunodetection of NADPH-cytochrome P450 reductase in rat testis. (a) Stained with the antibody raised against rat NADPH-cytochrome P450-reductase. (b) Stained with the same antibody preadsorbed with purified rat NADPH-Cytochrome P450 reductase. Arrows, staining in elongated spermatids and residual bodies; arrowheads, staining in Leydig cells. Bar represents $50 \mu \mathrm{m}$.

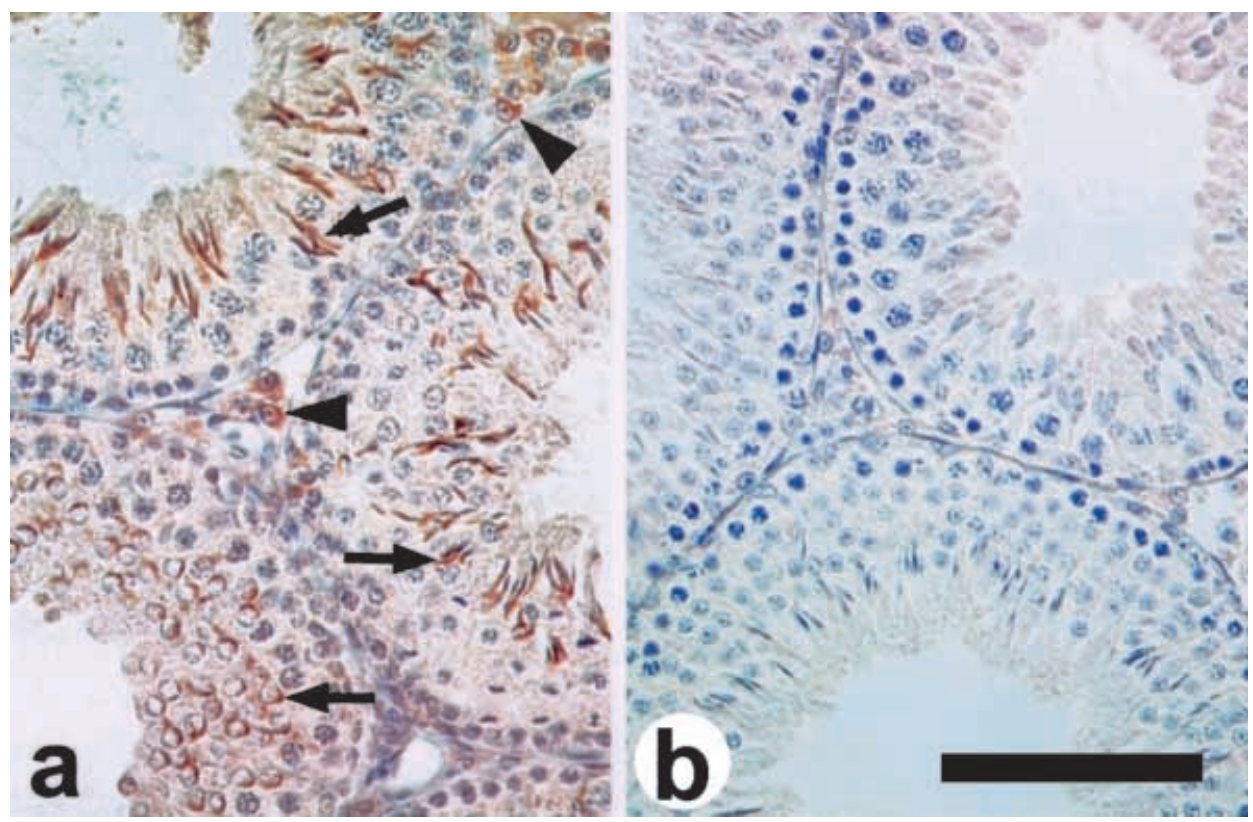

Figure 6 Immunodetection of squalene synthase in rat testis. (a) Stained with the antibody raised against the C-terminal peptide of a truncated squalene synthase protein (Thompson et al. 1998). (b) Stained with the same antibody preadsorbed with the purified truncated squalene synthase protein. Arrows, staining in acrosomes of round and elongated spermatids; arrowheads, staining in Leydig cells. Bar represents $50 \mu \mathrm{m}$. 
rats. The average values and standard errors of the means were $12.9 \pm 4 \cdot 8 \mathrm{pmol} / \mathrm{mg}$ per min for CYP51 activity in total liver proteins and $20.8 \pm 8.6 \mathrm{pmol} / \mathrm{mg}$ per min for activity in liver microsomes. In the same group of sexually mature animals, the activities were $10 \cdot 3 \pm 2 \cdot 8 \mathrm{pmol} / \mathrm{mg}$ per min in total testis proteins and $2 \cdot 4 \pm 0.9 \mathrm{pmol} / \mathrm{mg}$ per min in germ cell proteins (Strömstedt et al. 1998).

\section{Discussion}

It is widely accepted that the presqualene portion of cholesterol biosynthesis generates intermediates that have additional biological roles (precursors of heme and ubiquinone synthesis, farnesylation and geranylation of proteins, etc.). However, according to current dogma, the postsqualene portion of this pathway is committed to cholesterol biosynthesis. Recent isolation of two intermediates of the postsqualene portion of this pathway that have the capacity to reinitiate meiosis, from human follicular fluid (FF-MAS) and from bull testis (T-MAS) (Byskov et al. 1995), demonstrated that late intermediates of cholesterol biosynthesis may also accumulate and may serve roles not committed to cholesterol, at least in gonads.

Our goal was to establish which tissues or cell types allow production of sterols by the CYP51-catalyzed reaction, lanosterol 14a-demethylation. Our previous studies had unexpectedly shown the level of CYP51 mRNA to be one order of magnitude greater in testis than in liver of normally fed, sexually mature rats (Strömstedt et al. 1998). In contrast to the expression of CYP51 mRNA, its enzymatic activity in liver exceeds that in testis by about $30 \%$, the Leydig cells and postmeiotic germ cells contributing mainly to this activity (Strömstedt et al. 1998). This suggests that in testis only a small portion of CYP51 mRNA may be translated into protein, that translation itself may be stage-delayed, or that the CYP51 protein may have a rapid turnover. A comparison of the profile of expression of CYP51 mRNA (Strömstedt et al. 1998) with that of protein (this work) has shown both mRNA and protein to be detectable at the early round spermatid stage. Thus the CYP51 message is translated to protein with no time delay, and translation also continues in later stages that lack mRNA synthesis (stage VIII and on, step 8-19 of spermiogenesis). We believe that high levels of CYP51 mRNA are needed to assure sufficient template for protein synthesis after transcription is shut off. We are so far unable to explain why the CYP51 mRNA level (Strömstedt et al. 1998), the CYP51 protein level (this study) and the MAS sterol concentration (M Baltsen, M Parvinen and A-G Byskov, unpublished data) decrease in step 15-18 (stages I-VI) elongating spermatids. The background levels of CYP51 mRNA present at these stages seem to be sufficient to allow translation to protein even in step 19 spermatids. Whereas in the liver all hepatocytes appear to express CYP51 (this study) and
NADPH-cytochrome $\mathrm{P} 450$ reductase proteins (Taira et al. 1980, Wolf et al. 1984), this seems to be true only for certain cell types of the testis. Besides being present in Leydig cells, large amounts of both proteins reside in step 19 elongating spermatids and residual bodies. This suggests that the absence (or very low levels) of CYP51 enzyme at particular stages of spermatogenesis may not be the only reason for lower CYP51 enzyme activity in testis. The electron-transferring enzyme NADPH-P450 reductase, which is needed for CYP51 activity, may also be a limiting factor.

Until this report, very little has been known about expression of cholesterogenic enzymes in testis. The major obstacle is the lack of immunoreactive antibodies with which to detect the transmembrane proteins involved in cholesterol biosynthesis. A fusion protein of bacterial anthranilate synthase and rat farnesyl pyrophosphate (FPP) synthase was used to prepare antibodies that made possible studies of sterol dietary regulation of the liver and testis FPP proteins, showing dietary response in liver but not in testis (Ashby \& Edwards 1989). We have produced antibodies against the truncated human squalene synthase protein and the bacterially expressed human CYP51 protein, which enabled us to follow the expression of both cholesterogenic enzymes. Our results have shown that the two proteins are not co-expressed in all spermatogenesis stages, but both are expressed in liver. Previous studies of squalene synthase and CYP51 mRNA expression (Strömstedt et al. 1998) and the mechanism of CYP51 transcriptional regulation (Rozman et al. 1999) also indicated differences in regulation of the cholesterogenic pathway in liver compared with that in testis (germ cells). Male germ cell development proceeds for several weeks (Russell et al. 1990), and discordant expression of enzymes of cholesterol biosynthesis may lead to transient accumulation of intermediates in a particular cell type at a specific time during germ cell development. Whereas, in the liver, all cholesterogenic genes seem to be upregulated coordinately by the sterol/SREBP pathway with the aim of maintaining cholesterol synthesis, spermatids invoke different mechanisms to regulate expression of cholesterogenic genes, which may lead to accumulation of pathway intermediates (Rozman et al. 1999). The coexpression of CYP51 and of NADPH-cytochrome $\mathrm{P} 450$ reductase proteins in step 19 spermatids suggests that these haploid cells have the potential for in situ production of FF-MAS. MAS sterols are able to reinitiate meiosis in mouse oocytes in vitro (Byskov et al. 1995). As oocytes complete the secondary meiotic division only after fertilization, spermatid-produced MAS sterols might trigger the quiescent oocyte to complete the second meiotic division upon oocyte-sperm fusion. It is interesting to note that MAS sterol concentration is an order of magnitude greater in testis than in the ovaries (Byskov et al. 1999). In addition, the presence of functional CYP51 in residual bodies could be important for in situ MAS sterol 
production and initiation of meiosis in the testis itself. After being separated from mature spermatids, residual bodies move towards the basement membrane, where they are degraded by Sertoli cells (Jegou 1993, Syed et al. 1993, 1995, Hakorvita et al. 1995). Accordingly, MAS sterols, delivered by residual bodies into the vicinity of premeiotic germ cells, could trigger meiosis.

The exact physiological significance of the expression of CYP51 and squalene synthase in male germ cells remains unknown. Studies with selective and potent squalene synthase inhibitors that have been developed as cholesterol-decreasing agents (Hayward et al. 1997) led to testicular germ cell lesions in animal toxicology studies (Camacho et al. 1998). This indicates that the postsqualene cholesterol biosynthetic pathway in germ cells is needed for normal spermatogenesis. Whether the endproduct, cholesterol, or one of the pathway intermediates is the key substance, remains to be determined.

In conclusion, this study has provided evidence that most mature, step 19 elongated spermatids and residual bodies of the rat testis have the capacity to produce MAS sterols in situ. It has also provided evidence that two key enzymes of cholesterol biosynthesis (squalene synthase and CYP51) are not expressed at same levels during all stages of spermatogenesis. Differential expression of late cholesterogenic genes may be a more general mechanism to explain the transient accumulation of cholesterogenic intermediates, with yet unrevealed roles, in vivo.

\section{Acknowledgements}

The authors would like to thank Dr Philippa Saunders (MRC - Reproductive Biology Unit, Edinburgh, Scotland) for providing rat tissue, Dr Fred P Guengerich (Vanderbilt University, School of Medicine, Nashville, TN, USA) for providing NADPH-P450 reductase antibody, Dr Jim Trzaskos (DuPont-Merck, Wilmington, DW, USA) for providing standards, substrates and inhibitors for lanosterol 14 $\alpha$-demethylase assay, and Dr Jasna Šinkovec (Clinic for Gynaecology, Ljubljana, Slovenia) for use of the immunocytochemistry laboratory. We wish also to thank Dr Willam E Rainey (UT-Southwestern Medical Center, Dallas, TX, USA) for help in preparing the photomicrographs.

This work was supported by grants from the Ministry of Science of Slovenia Z1-7225-381 and SLO-US 0002, by grant $9650310 \mathrm{~N}$ from the American Hearth Association (Pfizer Award) and by grants from the Sigrid Jusélius Foundation.

\section{References}

Aoyama Y, Funae Y, Noshiro M, Horiuchi T \& Yoshida Y 1994 Occurrence of a P450 showing high homology to yeast lanosterol 14-demethylase (P45014DM) in the rat liver. Biochemical and Biophysical Research Communication 201 1320-1326.
Aoyama Y, Noshiro M, Gotoh O, Imaoka S, Funae Y, Kurosawa N, Horiuchi T \& Yoshida Y 1996 Sterol 14-demethylase P450 (P45014DM) is one of the most ancient and conserved P450 species. Journal of Biochemistry 119 926-933.

Ashby MN \& Edwards PA 1989 Identification and regulation of a rat liver cDNA encoding farnesyl pyrophosphate synthase. Journal of Biological Chemistry 264 635-640.

Brown MS \& Goldstein JL 1998 Sterol regulatory element binding proteins (SREBPs): controllers of lipid synthesis and cellular uptake. Nutrition Reviews 56 S1-S3.

Byskov AG, Andersen CY, Nordholm L, Thogersen H, Guoliang X, Wassman O, Guddal JVAE \& Roed T 1995 Chemical structure of sterols that activte oocyte meiosis. Nature 374 559-562.

Byskov A-G, Andersen CY, Leonardsen L \& Baltsen M 1999 Meiosis activating sterols (MAS) and fertility in mammals and man. Journal of Experimental Zoology 285 237-242.

Camacho D, Gerhardt C, Ku WW, Shah T, Day W, Roesler AR, Floyd E, Foley G \& Mayne JT 1998 Testicular changes in rats after subchronic oral administration of the squalene synthase inhibitor CP-340,868. Toxicologist 4247.

Cross NL 1998 Role of cholesterol in sperm capacitation. Biology of Reproduction 59 7-11.

Fischer RT, Trzaskos JM, Magolda RL, Ko SS, Brosz CS \& Larsen B 1991 Lanosterol 14a-methyl demethylase. Journal of Biological Chemistry 266 6124-6132.

Goldstein JL \& Brown MS 1990 Regulation of the mevalonate pathway. Nature 343 425-430.

Grondahl C, Ottesen JL, Lessl M, Faarup P, Murray A, Gronvald FC, Hegelehartung C \& Ahnfeltronne I 1998 Meiosis-activating sterol promotes resumption of meiosis in mouse oocytes cultured in vitro in contrast to related oxysterols. Biology of Reproduction $\mathbf{5 8}$ 1297-1302.

Guengerich FP, Wang P \& Mason PS 1981 Immunological comparison of rat, rabbit and human liver NADPH-cytochrome P-450 reductases. Biochemistry 20 2379-2385.

Guengerich FP, Churchill PF, Jung CY \& Fleischer S 1987 Target inactivation analysis applied to determination of molecular weights of rat liver proteins in the purified state and in microsomal membranes. Biochimica et Biophysica Acta 915 246-253.

Gunasegaram R, Peh KL, Loganath A, Chew PCT \& Ratnam SS 1995 in vitro formation of $\left[{ }^{14} \mathrm{C}\right]$-cholesterol from $2-\left[{ }^{14} \mathrm{C}\right]$-acetate in human spermatozoa. Medical Science Research 23 315-316.

Hakorvita H, Syed V, Jegou B \& Parvinen M 1995 Function of interleukin-6 as an inhibitor of meiotic DNA synthesis in the rat seminiferous epithelium. Molecular Cellular Endocrinology 108 193-198.

Halkier BA, Sibbesen O \& Moeller BL 1996 Isolation of plant and recombinant CYP79. In Methods in Enzymology, pp 268-274. Eds EF Johnson \& MR Waterman. San Diego, CA: Academic Press.

Hayward CM, Hamanaka RJ, Aiello RJ, Harwood HJJ, Aldinger CE, Bagley SW, Bourassa PA, Godard LM, Hada WA, Johnson DA, Lindsey S, Long CA, Martingano RJ \& Petras SF 1997 Discovery of the squalene synthase inhibitor CP-340,868. Atherosclerosis 134 125.

Imai T, Globerman H, Gertner JM, Kagawa N \& Waterman MR 1993 Expression and purification of functional human $17 \alpha-$ hydroxylase/17,20-lyase (P450c17) in Escherichia coli. Journal of Biological Chemistry 268 19681-19689.

Jegou B 1993 The Sertoli-germ cell communication network in mammals. International Review of Cytology 147 25-96.

Jenkins C \& Waterman MR 1998 E. coli two-component microsomal P450 reductase. Biochemistry 37 6107-6113.

Meistrich ML, Bruce WR \& Clermont Y 1973 Cellular composition of fractions of mouse testis following velocity sedimentation separation. Experimental Cell Research 79 213-227.

Millar MR, Sharpe RM \& Sounders PTK 1993 Cellular localisation of messenger RNAs in rat testis: application of digoxigenin labelled probes to embedded tissue. Cell and Tissue Research 273 269-277. 
Nelson DR 1999 Cytochrome P450 and the individuality of species. Archives of Biochemistry and Biophysics 369 1-10.

Noshiro M, Aoyama Y, Kawamoto T, Gotoh O, Horiuchi T \& Yoshida Y 1997 Structural and evolutionary studies on sterol $14 \alpha$-demethylase P450 (CYP51), the most conserved monooxygenase: I. Structural analyses of the gene and multiple sizes of mRNA. Journal of Biochemistry 122 1114-1121.

Parvinen M \& Vanha-Perttula T 1972 Identification and enzyme quantitation of the stages of the seminiferous epithelial wave in the rat. Anatomical Reviews 174 435-450.

Rozman D, Strömstedt M, Tsui L-C, Scherer SW \& Waterman MR 1996a Structure and mapping of the human lanosterol $14 \alpha-$ demethylase gene (CYP51) encoding the cytochrome P450 involved in cholesterol biosynthesis; comparison of exon/intron organization with other mammalian and fungal CYP genes. Genomics 38 371-381.

Rozman D, Strömstedt M \& Waterman MR 19966 The three human cytochrome P450 lanosterol 14 $\alpha$-demethylase (CYP51) genes reside on chromosomes 3,7 and 13: structure of the two retrotransposed pseudogenes, association with a LINE-1 element and evolution of the human CYP51 family. Archives of Biochemistry and Biophysics 333 466-474.

Rozman D, Fink M, Fimia G-M, Sassone-Corsi P \& Waterman MR 1999 Cyclic adenosine 3',5'-monophosphate (cAMP)/cAMPresponsive element modulator (CREM)-dependent regulation of cholesterogenic lanosterol $14 \alpha$-demethylase in spermatids. Molecular Endocrinology 13 1951-1962.

Russell DL, Ettlin RA, Hikim APS \& Clegg ED 1990 Histological and histopathological evaluation of the testis. Clearwater, FI: Cache River Press.

Shi S-R, Chaiwun B, Young L, Cote R \& Taylor C 1993 Antigen retrieval technique utilizing citrate buffer or urea solution for immunohistochemical demonstration of androgen receptor in formalin-fixed paraffin sections. Journal of Histochemistry and Cytochemistry 41 1599-1604.

Shyadehi AZ, Lamb DC, Kelly SL, Kelly DE, Schunk W-H, Wright JN, Corina D \& Akhtar M 1996 The mechanism of the acylcarbon bond cleavage reaction catalyzed by recombinant sterol $14 \alpha$-demethylase of Candida albicans (other names are: lanosterol $14 \alpha$-demethylase, P-45014DM and CYP51). Journal of Biological Chemistry 271 12445-12450.
Strömstedt M, Rozman D \& Waterman MR 1996 The ubiquitously expressed human CYP51 encodes lanosterol 14 $\alpha$-demethylase, a cytochrome $\mathrm{P} 450$ whose expression is regulated by oxysterols. Archives of Biochemistry and Biophysics 329 73-81.

Strömstedt M, Waterman MR, Haugen TB, Taskén K, Parvinen M \& Rozman D 1998 Elevated expression of lanosterol 14ademethylase (CYP51) and the synthesis of oocyte meiosisactivating sterols in postmeiotic germ cells of male rats. Endocrinology $1392314-2321$

Syed V, Gerard N, Kapia A, Bardin CW, Parvinen M \& Jegou B 1993 Identification, ontogeny, and regulation of an interleukin-6like factor in the rat seminiferous tubule. Endocrinology 132 293-299.

Syed V, Stephan J-P, Gerard N, Legrand A, Parvinen M, Bardin CW \& Jegou B 1995 Residual bodies activate Sertoli cell interleukin$1 \alpha(\mathrm{IL}-1 \alpha)$ release, which triggers IL-6 production by an autocrine mechanism, through the lipoxygenase pathway. Endocrinology 136 3070-3078

Taira Y, Redick JA \& Baron J 1980 An immunohistochemical study on the localization and distribution of NADPH-cytochrome c(P450) reductase in rat liver. Molecular Pharmacology 17 374-381.

Thompson JF, Danlez DE, Mazzalupo S, Milos PM, Lira ME \& Harwood HJJ 1998 Truncation of human squalene synthase yields active, crystallizable protein. Archives of Biochemistry and Biophysics $350283-290$

Trzaskos J, Kawata S \& Gaylor JL 1986 Microsomal enzymes of cholesterol biosynthesis. Journal of Bological Chemistry 261 14651-14657.

Wolf CR, Moll E, Friedberg T, Oesch F, Buchmann A, Kuhlmann WD \& Kunz HW 1984 Characterization, localization and regulation of a novel phenobarbital-inducible form of cytochrome P450, compared with three further P450-isoenzymes, NADPH P450-reductase, glutathione transferase and microsomal epoxide hydroxylase. Carcinogenesis 5 993-1001.

Received 28 January 2000

Accepted 6 April 2000 